ANL-5804

Chemistry-General

ARGONNE NATIONAL LABORATORY

P. O. Box 299

Lemont, Illinois

AN X-RAY SPECTROMETRIC METHOD FOR DETERMINATION

OF PLUTONIUM IN SOLUTION

by

D. S. Flikkema and R. V. Schablaske

Chemical Engineering Division

November 1957

Operated by The University of Chicago

under

Contract W-31-109-eng-38 


\section{DISCLAIMER}

This report was prepared as an account of work sponsored by an agency of the United States Government. Neither the United States Government nor any agency Thereof, nor any of their employees, makes any warranty, express or implied, or assumes any legal liability or responsibility for the accuracy, completeness, or usefulness of any information, apparatus, product, or process disclosed, or represents that its use would not infringe privately owned rights. Reference herein to any specific commercial product, process, or service by trade name, trademark, manufacturer, or otherwise does not necessarily constitute or imply its endorsement, recommendation, or favoring by the United States Government or any agency thereof. The views and opinions of authors expressed herein do not necessarily state or reflect those of the United States Government or any agency thereof. 


\section{DISCLAIMER}

Portions of this document may be illegible in electronic image products. Images are produced from the best available original document. 


\title{
AN X-RAY SPECTROMETRIC METHOD FOR DETERMINATION OF PLUTONIUM IN SOLUTION
}

by

D. S. Flikkema and R. V. Schablaske

\begin{abstract}
It is shown that the method of $X$-ray emission spectrometry can be extended advantageously to the determination of plutonium in solution. Since $K$ and $L \mathrm{X}-\mathrm{ray}$ emission from the elements of higher atomic number is notmeasurably influenced by valence state of the emitting atom or ion, this physical method is especially attractive for elements such as plutonium whose chemistry is intricate and whose chemical analysis is complicated by severalvalence states existing in solution. Nor is it affected by variations in isotopic content as is the widely used radiochemical assay for plutonium.

With a total amount of plutonium between 0.4 and $0.8 \mathrm{mg}$ the standard deviation of a single result is less than 1 per cent. For samples of diverse origin interferences are eliminated, usually by simple chemical pre-treatment or by separation procedures, to give a clean solution for analysis. On the other hand, for large numbers of samples with a comparable matrix, it is worthwhile to devis. calibration standards so that such samples can be analyzed directly.
\end{abstract}

\section{INTRODUCTION}

The reliability and usefulness of $\mathrm{X}$-ray spectrometry for determining uranium in solution 1 led to efforts which would adapt it for plutoni um analysis. From the outset this physical method appeared especially attractive for plutonium because of several characteristics. Being independent of the valence state of the emitting atom or ion, X-ray spectral analysis removes this factor from concern for elements such as plutonium whose chemistry is intricate and whose chemical analysis is complicated by as many as four different valence states in solution. 2 Isotopic content

1 Flikkema, D. S., Larsen, R. P., and Schablaske, R. V., "The X-ray Spectrometric Determination of Uranium in Solution," ANL-5641 (November 1956).

${ }^{2}$ Connick, R. E., "Oxidation States, Potentials, Equilibria, and Oxidation-Reduction Reactions of Plutonium, "Chapter 8 in "The Actinide Elements," NNES, IV-14A (1954). 
can be neglected also, in contrast with the radiochemical method which is used for determining absolute amounts of plutonium in laboratories equipped to establish its specific activity by mass spectral and alpha pulse analysis. 3

The sensitivity and simplicity inherent in the $\mathrm{X}$-ray emission method gave promise that reliable results should be obtainable with much less plutonium than is required for the classical types of methods which are used, thus reducing the personal hazard from this alpha emitter. The usual titrimetric procedures, all of which are based on the plutonium III-IV couple with variations in preliminary reductant and method of endpoint detection, involve 10 to 15 milligrams of the element and require correction for any iron and uranium present. Procedures which depend on characteristic absorption in the visible spectrum by the various ionic species of plutonium in solution are not notably sensitive. Gravimetric procedures are seldom applied, except to referee other methods, because of the difficulties in handling weighable amounts of dry plutonium compounds. More versatile than the se is a recent coulometric method ${ }^{4}$ based on preliminary oxidation to $\mathrm{Pu}$ (VI) followed by titration to $\mathrm{Pu}$ (IV) with electrolytically generated $\mathrm{Fe}$ (II); most of the interferences in this method can be eliminated by first precipitating the plutonium as its tetrafluoride on a lanthanum fluoride carrier.

Since plutonium in the form of dry compounds becomes air-borne in a seemingly insidious way, it is much easier to contain and to handle the element in solution. This advantage of solutions over powders is enhanced by other features when analysis by $\mathrm{X}$-ray spectrometry is considered: an internal standard can be added conveniently to a solution, uniformity of the sample is assured, and the particle size effect ${ }^{5}$ does not appear. Moreover, as the solution of a material is diluted the solvent becomes the major contributor to the matrix effect, thus masking variability in the original solid matrix.

The $\mathrm{X}$-ray spectrometric method described here is applied to plutonium in the concentration range from 2 to $8 \times 10^{-3}$ molar, with the standard deviation of a single result \pm 1.5 percent and \pm 0.6 percent at the limits of this concentration range for total counting times less than eleven minutes. One-half milliliter of solution is used for each determination, so that the amount of plutonium required is less than one milligram. For large numbers of samples having matrices whose constituents are known and whose compositions are known to be similar, it is worthwhile to devise a calibration so that such samples can be analyzed directly

${ }^{3}$ Seaborg, G. T., "Nuclear Properties of the Plutonium Isotopes," Chapter 7 in "The Actinide Elements," NNES, IV-14A (1954).

${ }^{4}$ Carson, W. N., Jr., Vanderwater, J. W., and Gile, H. S., Anal. Chem. 29, 1417 (1957).

5 Adler, I., and Axelrod, J. M., Spectrochimica Acta 7, 97 (1955). 
for their plutonium content. On the other hand, for samples of diverse origin the plutonium is first separated by a procedure of choice, including carrier precipitation, adsorption-elution and/or solvent extraction, which will yield a solution clean enough for reliable spectrometric analysis. The considerations relevant to interference effects are discussed in ANL-5641.1

\section{DESCRIPTION OF APPARATUS}

Instrument

The $\mathrm{X}$-ray spectrograph used in this work was a basic Norelco instrument modified as previously described 1 except for the circuit of the $\mathrm{X}$-ray tube current stabilizer. In this case primary $\mathrm{X}$-radiation is provided with a Norelco type FA-60 tungsten target tube and stabilized by a Norelco circuit having a Thyratron for control. Since this regulating device is inherently limited to a degree of control which permits an excessive error contribution by the instrument, it is being replaced by a circuit which will give the desired stabilization of emission current.

The secondary radiation from the sample was analyzed by diffaction from a lithium fluoride crystal cut for the (200) plane. A parallel plate collimator, ratio 800 to 1 , was interposed between the crystal and the counter. Counting was done at a goniometer setting of 24.90 degrees, the $2 \theta$ angular location for the PuL $\alpha_{1}$ line from the lithium fluoride analyzer. For convenient reference, Table 1 lists the energies, wavelengths and reflection angles from the lithium fluoride and topaz analyzers for the principal $L$ series X-ray emission lines of uranium, plutonium and adjacent elements. This listing is arranged in increasing order of wavelengths and also gives the corresponding absorption edges.

Sample Cells

The spectrometer sample cells for plutonium solutions were allglass, constructed as described and shown in ANL-5641. In order to keep down the amount of plutonium handled, the cell volume was less than one. tenth that used in a typical uranium determination. Typically, a plutonium cell was $8 \mathrm{~mm}$ in diameter, $7 \mathrm{~mm}$ in height, and had a window $0.075 \mathrm{~mm}$ thick; the capacity including the two side-arms was $0.5 \mathrm{ml}$. The cell was fixed in position for maximum intensity by cementing it in an aluminum tray. This tray, which was large enough to contain the solution should the cell crack or break, was mounted in the instrument specimen holder under aluminum spring clips. As a further precaution, a fitted liquid-tight Lucite box was used for carrying the filled cell and specimen holder between the laboratory hood and the instrument. 
Table 1

PRINCIPAL I. SERIES X-RAY EMISSION LINES OF URANIM, PLUTONIIM AND ADJACENT ELEMEVTS, ARRAYGED IA ORDER OF INCREASING WAVEIENGTH

\begin{tabular}{|c|c|c|c|c|c|c|c|c|c|c|c|}
\hline \multirow[b]{2}{*}{$\begin{array}{c}\text { Frission } \\
\text { Line }\end{array}$} & \multirow[b]{2}{*}{$\begin{array}{c}\text { Energy } \\
\text { (hey) }\end{array}$} & \multirow[b]{2}{*}{$\begin{array}{l}\text { Wavel engt } \\
\text { (angstroms) }\end{array}$} & \multirow[b]{2}{*}{$\begin{array}{l}\text { Absorption } \\
\text { Edge } \\
\text { (angstroms) }\end{array}$} & \multicolumn{2}{|c|}{$\begin{array}{l}\text { Reflection Angle, } \\
\text { Degrees } 2 t \text {, from }\end{array}$} & \multirow[b]{2}{*}{$\begin{array}{l}\text { Limission } \\
\text { Line }\end{array}$} & \multirow[b]{2}{*}{$\begin{array}{l}\text { Energy } \\
(\text { hev) } \\
\end{array}$} & \multirow[b]{2}{*}{$\begin{array}{l}\text { Wavel ength } \\
\text { (angstroms) }\end{array}$} & \multirow[b]{2}{*}{$\begin{array}{c}\text { Absorption } \\
\text { Edge } \\
\text { (angstroms) }\end{array}$} & \multicolumn{2}{|c|}{$\begin{array}{l}\text { Reflection Angle, } \\
\text { Degrees } 2 t^{3} \text { from }\end{array}$} \\
\hline & & & & $\begin{array}{c}\text { Lithium } \\
\text { Fluoride } \\
2 \mathrm{~d}=4.02 \% \AA\end{array}$ & $\begin{array}{c}\text { Topaz } \\
(2 \mathrm{~d}=2.712 \quad \mathrm{~A}) \\
\end{array}$ & & & & & 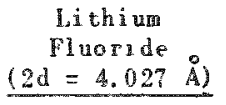 & $\begin{array}{c}\text { Topaz } \\
(2 \mathrm{~d}=2.712 \AA)\end{array}$ \\
\hline IL, 1 & $24.16 \%$ & 0.6148 & 0.5919 & 17.36 & 26.21 & $\operatorname{CnaL} \gamma_{1}$ & 14.961 & 0.8286 & 0.6528 & 23.75 & 35.58 \\
\hline$\overline{\mathrm{Pal}_{1}}$ & 19.559 & 0.6338 & 0.6103 & 18.11 & 27.03 & $\mathrm{RaL}_{2}$ & 14.839 & 0.8354 & 0.8028 & 23.95 & 35.88 \\
\hline $\operatorname{ConL}=1$ & 19.303 & 0.6392 & 0.524 .4 & $18.2 \%$ & 27.27 & $\mathrm{PbL} y_{1}$ & 14.962 & $0.839 \%$ & 0.8152 & 24.07 & $36.0 ?$ \\
\hline ThL ${ }_{1}$ & 18.977 & 0.6532 & 0.6290 & 18.67 & $2 \% .87$ & $\mathrm{CmL} a_{2}$ & 14.73 & 0.8408 & 0.6528 & 24.10 & 35.12 \\
\hline Aral ${ }^{2}{ }_{1}^{2}$ & $\begin{array}{l}18.829^{\mathrm{a}} \\
18.845^{\mathrm{b}}\end{array}$ & $\begin{array}{l}0.6584 \\
0.6578\end{array}$ & 0.5403 & $\begin{array}{l}18.82 \\
18.80\end{array}$ & $\begin{array}{l}38.10 \\
38.0 ?\end{array}$ & $\operatorname{AmL} x_{1}$ & $\begin{array}{l}14.618^{a} \\
14.614^{b}\end{array}$ & $\begin{array}{l}0.8480 \\
0.8482\end{array}$ & 0.6692 & $\begin{array}{l}24.31 \\
24.32\end{array}$ & $\begin{array}{l}36.45 \\
36.45\end{array}$ \\
\hline AcL ${ }_{1}$ & 18.405 & 0.6735 & 0.6498 & 10.25 & 28.76 & AmL $x_{2}$ & $14.411^{\mathrm{a}}$ & $0.8+02$ & 0.6693 & 24.67 & 36.99 \\
\hline$\stackrel{\text { PuL }}{1}_{1}$ & $\begin{array}{l}\text { 18. } 398^{3} \\
18.290^{1}\end{array}$ & $\begin{array}{l}11.6782 \\
0.67 .8\end{array}$ & 0.5568 & $\begin{array}{l}19.39 \\
19.38\end{array}$ & $\begin{array}{l}38.9 n \\
28.95\end{array}$ & III, & $\begin{array}{l}14.140^{\circ 8} \\
14.288\end{array}$ & $\begin{array}{l}0.8504 \\
0.8676\end{array}$ & 0.8435 & $\begin{array}{l}24.6 ? \\
24.88\end{array}$ & $\begin{array}{l}36.99 \\
37.32\end{array}$ \\
\hline $\begin{array}{l}\text { Conl. } \\
\text { Ral. }{ }_{1}\end{array}$ & $\begin{array}{l}19.1606 \\
17.915\end{array}$ & $\begin{array}{l}0.684 \% \\
0.694 \%\end{array}$ & $\begin{array}{l}6.0528 \\
0.6 .08\end{array}$ & $\begin{array}{l}19.58 \\
19.87\end{array}$ & $\begin{array}{l}29.25 \\
29.68\end{array}$ & $\operatorname{PuL} a_{1}$ & $\begin{array}{l}14.90^{3} \\
14.278^{b}\end{array}$ & $\begin{array}{l}0.8682 \\
0.8682\end{array}$ & 0.0862 & 24.90 & 37.34 \\
\hline $\mathrm{V}_{\mathrm{P}} \mathrm{L}$ & $\begin{array}{l}17.70^{a} \\
10.747^{b}\end{array}$ & $\begin{array}{l}0.0988 \\
0.0980\end{array}$ & 0.58 .30 & $\begin{array}{l}19.96 \\
14.97\end{array}$ & $\begin{array}{l}29.86 \\
29.8 n\end{array}$ & $\stackrel{\mathrm{PuI} \cdot \mathrm{a}_{2}}{=}$ & $\begin{array}{l}14.082^{\mathrm{a}} \\
14.093^{\mathrm{b}}\end{array}$ & $\begin{array}{l}0.8803 \\
0.8802\end{array}$ & 0.6862 & $\begin{array}{l}25.25 \\
25.25\end{array}$ & $\begin{array}{l}37.88 \\
3^{7} .88\end{array}$ \\
\hline Anl ${ }_{2}$ & $\begin{array}{l}1 \% 677^{4} \\
17.6725\end{array}$ & $\begin{array}{l}0.0013 \\
0.0013\end{array}$ & $0 . \tan 42$ & $\begin{array}{l}20.0 \% \\
20.0 t\end{array}$ & $\begin{array}{l}29.9 ? \\
29.98\end{array}$ & $\operatorname{VpL} x_{1}$ & $\begin{array}{l}13.945^{\mathrm{a}} \\
13.940^{\mathrm{k}}\end{array}$ & $\begin{array}{l}0.8890 \\
0.8893\end{array}$ & 0.7038 & $\begin{array}{l}25.51 \\
25.52\end{array}$ & $\begin{array}{l}38.29 \\
38.28\end{array}$ \\
\hline $\mathrm{PuL}{ }_{2}$ & $\begin{array}{l}17.254 a \\
17.252 b\end{array}$ & $\begin{array}{l}0.7185 \\
0.7186\end{array}$ & 0.0862 & $\begin{array}{l}20.56 \\
20.56\end{array}$ & $\begin{array}{l}30.73 \\
30.73\end{array}$ & $\begin{array}{l}\lg L_{\gamma_{1}} \\
\operatorname{pl} h_{2}\end{array}$ & $\begin{array}{l}13.828 \\
13.758 \mathrm{a}\end{array}$ & $\begin{array}{l}0.8965 \\
0.9010\end{array}$ & $\begin{array}{l}0.8723 \\
0.7038\end{array}$ & $\begin{array}{l}25.73 \\
25.86\end{array}$ & $\begin{array}{l}38.61 \\
38.81\end{array}$ \\
\hline LL 1 & 17.218 & $0 .-2000$ & 0.5919 & 281.60 & 30.79 & & $13.758^{5}$ & & & & \\
\hline$\frac{1}{\sqrt{p L}}$ & $\begin{array}{l}16.833^{\mathrm{a}} \\
16.833^{\mathrm{b}}\end{array}$ & $\begin{array}{l}18.7363 \\
0.7364\end{array}$ & 0.7038 & $\begin{array}{l}21.0 \% \\
21.0^{\circ}\end{array}$ & $\begin{array}{l}31.51 \\
31.31\end{array}$ & $\frac{\mathrm{CL} \alpha_{1}}{\mathrm{PoL}}$ & $\begin{array}{l}13.613 \\
13.441\end{array}$ & $\begin{array}{l}0.9106 \\
0.9223\end{array}$ & $\begin{array}{l}0.7223 \\
0.7631\end{array}$ & $\begin{array}{l}20.14 \\
26.48\end{array}$ & $\begin{array}{l}39.24 \\
39.70\end{array}$ \\
\hline PaL"i & $16 .-00$ & 0.7123 & 0.6103 & 21.24 & 31.77 & $1 \mathrm{~L} \alpha_{2}$ & 13.438 & 0.0225 & 0.7233 & 26.49 & 39.75 \\
\hline U. 2 & 16.425 & 10.754 .7 & 10.2223 & 21.60 & 32.32 & $\overline{\operatorname{AuL}_{1}}$ & 13.379 & 0.9265 & 0.9027 & 26.60 & 39.95 \\
\hline$\overline{\text { ThI. }} \overline{1}$ & 16.200 & 0.7652 & 0.52966 & 21.91 & 32.78 & Poll ${ }_{2}$ & 13.338 & 0.9294 & 0.8972 & 26.69 & 40.08 \\
\hline $\mathrm{PaL}_{2}$ & 10.022 & $0.7 .3 \%$ & $0 . \sim 4 n G$ & 22.15 & 33.15 & $\mathrm{PaL}_{1}$ & 13.291 & 0.9327 & 0.7409 & 26.78 & 40.23 \\
\hline $\operatorname{PoL}_{1} y_{1}$ & 15.740 & 0.7876 & 0.7631 & 22.56 & 33.76 & $\mathrm{PaL} \alpha_{2}$ & 13.120 & 0.91 .49 & 0.7409 & 27.14 & 40.78 \\
\hline Acl 1 & $15 . .12$ & 0.7890 & 0.6498 & 22.60 & 33.83 & $\mathrm{Bill}_{2}, \mathbb{1}$ & 13.021 & 0.9520 & 0.7888 & 27.35 & 41.10 \\
\hline $\operatorname{ThL} \delta_{2}$ & 15.620 & 0.7936 & 0.7607 & 22.73 & 34.03 & $\mathrm{~B}_{1} \mathrm{LFs}_{2}$ & 12.977 & 0.9553 & 0.9235 & 27.45 & 41.25 \\
\hline$B i L_{1}$ & 15.244 & 0.8132 & 0.7888 & 23.30 & 34.90 & ThL $a_{1}$ & 12.966 & 0.9561 & $0.760 \%$ & 27.47 & 41.29 \\
\hline $\operatorname{RaL}_{\beta_{1}}$ & 15.233 & 0.8138 & 0.6708 & 83.32 & 34.92 & ThL $a_{2}$ & 12.808 & 0.9679 & 0.7607 & 27.81 & 41.82 \\
\hline $\mathrm{Acl}_{2}$ & 15.227 & 0.8141 & 0.7814 & 23.33 & 34.94 & & & & & & \\
\hline
\end{tabular}

${ }^{2}$ Fine, S., and Ilendee, C. F., Vucleonirs 13, 36 (1955): Values derived from absorption edges by calculation.

bogosa, G. L., and Peed, W. F., Phys. Rev. 101, 591 (1956): Lxperimental values. 
EXPERIMENTAL PROCEDURE AND RESULTS

\section{Choice of Conditions}

To control the final matrix composition and the plutonium concentration within the limits for reliable analysis, solutions were evaporated to dryness and the evaporates re-dissolved to the desired concentration in a selected solvent. Solvents were selected from among those giving stable plutonium solutions by comparing their matrix effects. Solutions ranging from $1.3 \times 10^{-3}$ to $9.7 \times 10^{-3}$ molar in plutonium were prepared by evaporating aliquots of a plutonium stock solution* to dryness under a heat lamp and taking up the evaporates to the desired plutonium concentrations in various solvent acids. Series of count rates at a fixed level of primary radiation were determined with these solutions and with solvent "blanks." From the results summarized in Table 2 and shown graphically in Figure 1 , it is apparent that $1 \mathrm{M}$ nitric acid as a solvent does not permit notably greater sensitivity $\left(\frac{\bar{\Delta} \text { Intensity }}{\Delta \text { Concentration }}\right)$ than 1 M hydrochloric acid. Moreover, the chemistry of plutonium makes the latter a more likely choice for most solution analyses. In this connection the data of Table 2 can be used together with calculated linear absorption coefficients to show that control over the solvent acid concentration must be much more rigorous for hydrochloric acid than for nitric acid if an inverse interference error is to be avoided.

The choice of operating kilovoltage and tube current for the primary $X$-ray generator is not critical. For analysis of plutonium solutions the settings chosen were $54 \mathrm{kvp} *$ and 43 milliamperes. At these levels the error contributed by the instrument to an analysis amounted to a relative standard deviation of 0.4 per cent. Operation at higher kilovoltages had the advantage of increasing the total number of counts registered per given length of time. On the other hand lower kilovoltages gave a lower background. The calculated statistical error of counting for a given length of time allowed a slight edge in favor of higher settings. Still it should be kept in mind that as maximum ratings, $60 \mathrm{kvp}$ and $50 \mathrm{ma}$, for this instrument are approached the rate at which some of its components deteriorate is ruinous.

Calibration

To define an analytical curve for a solvent matrix of 1 M nitric acid, eighteen solutions were prepared by evaporating aliquots of a plutonium stock solution to dryness under a heat lamp and then taking up the

*6.48 $\times 10^{-3} \mathrm{M} \mathrm{Pu}$ in $6 \underline{\mathrm{MC}} \mathrm{HC}$.

* This value is three times the energy level in kev of the relevant plutonium absorption edge. 
Table 2

\section{PLUTONIUU CONCENTRATION VS COUNT RATE IN VARIOUS VATRICES. 57 KVP, 47 MA}

Total Count Rate

Pu Molarity $\times 10^{3}$

0

1.30

2.59

6.48

9.72
(128,000 counts) (cps)

$\frac{11 \mathrm{HNO}_{3}}{197} \frac{1 \mathrm{~V} \mathrm{HCl}}{186} \quad \frac{4 \mathrm{M} \mathrm{HCl}}{170}$

24.4

290

416

508

$\begin{array}{ll}267 & 219 \\ 374 & 296 \\ 454 & 353\end{array}$

Fraction of Total Counts Due to Plutonium

$1 \underline{\mathrm{M}} \mathrm{HNO}_{3} \quad 1 \underline{\mathrm{MCl}} \quad 4 \underline{\mathrm{HCl}}$

0.19

0.32

0.53

0.61
0.30

0.50

0.59
0.22

0.43

0.52

FIGURE 1

RELATION OF THE ANALYTICAL SENSITIVITY $\left(\frac{\triangle I N T E N S I T Y}{\triangle \text { CONCENTRATION }}\right)$

FOR PLUTONIUM IN VARIOUS SOLUTION MATRICES

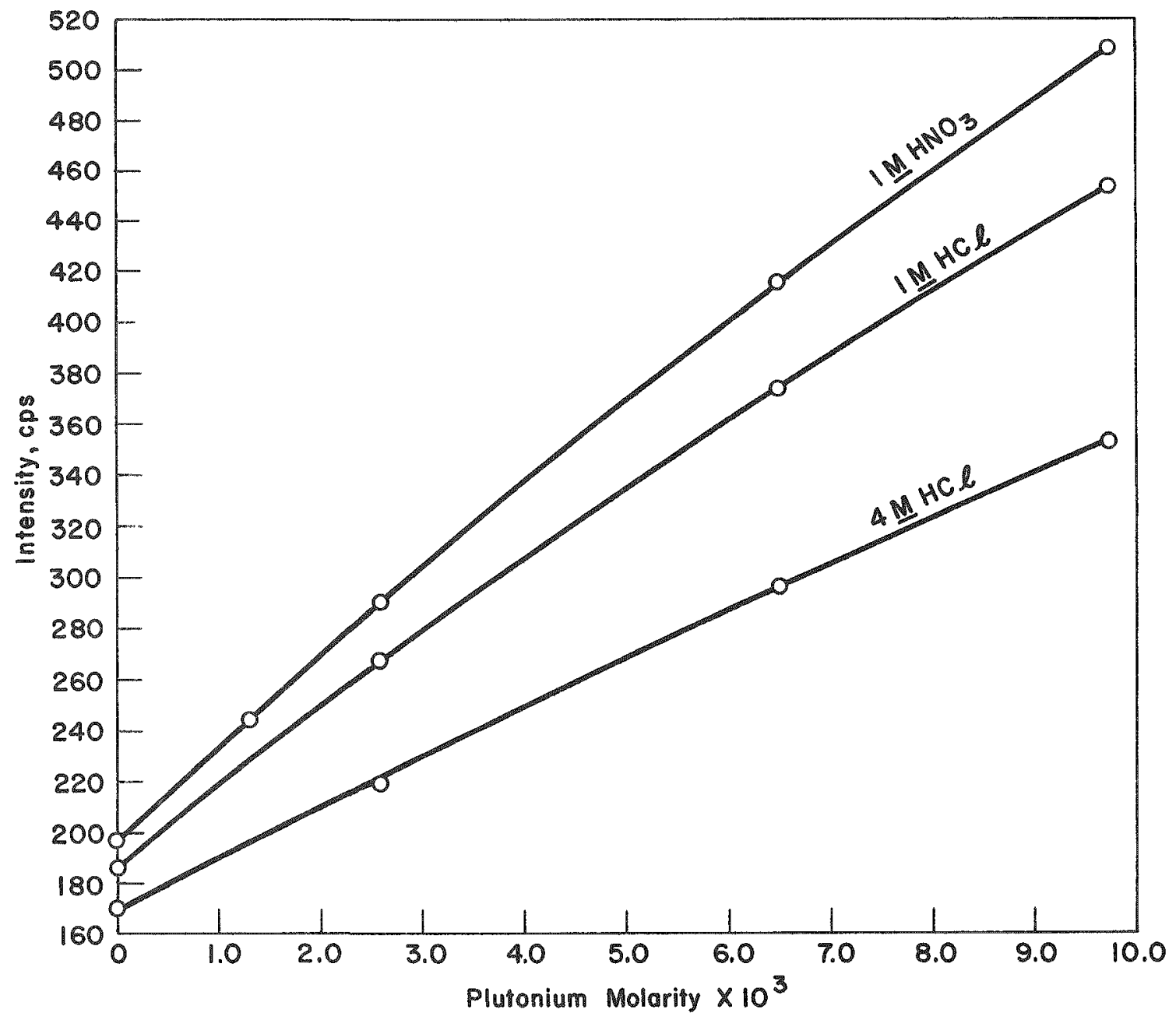


evaporates to the desired concentrations with $1.0 \mathrm{M}$ nitric acid. The concentrations were at six levels, three solutions each, from $1.9 \times 10^{-3}$ to $6.5 \times 10^{-3} \mathrm{M}$ in plutonium. Count rates were determined at $54 \mathrm{kvp}$ and $43 \mathrm{ma}$ from each of the se solutions and from solvent blanks. The recorded variable in each determination was the time required to register 128,000 total counts. At each concentration the three results were averaged and plotted to give the calibration relation, intensity vs.Pu molarity. Since these results give a rough idea of the precision which may be expected from the method under the conditions used, the data are listed in Table 3; the percent deviations found were compared with those expected from the statistics of counting, the latter calculated as usual by dividing the square root of the sum of the total count and of the background count (which would have been accumulated in the same time) by their difference. The standard deviation "found" was taken as 1.25 times the average deviation found, because of the small number of determinations at each concentration level.

To obtain a calibration for plutonium in $1.0 \mathrm{M}$ hydrochloric acid solutions, but more particularly to determine the inherent reliability of the method, another series was completed in a way which permitted the determinate errors to be evaluated or made negligible. Plutonium metal, analytically known within 3 parts/10000, was electropolished, weighed. and dissolved in hydrochloric acid to give a stock solution containing $13.53 \mathrm{mg}$ per gram of solution. Aliquots of this solution were carefully taken with calibrated pipets, delivered into tared weighing bottles, and weighed so that the error of the pipetting operation was known. The aliquots were evaporated to dryness in their $x$ espective weighing bottles under a heat lamp. After dissolution in 1.00 M hydrochloric acid the evaporates were quantitatively transferred to calibrated volumetric flasks and diluted to volume while thermostated at the temperature of the instrument room. The count rate determinations were made at $54 \mathrm{kvp}, 43 \mathrm{ma}$ in a continuous but random series, with the fixed count from a solution bracketed by equivalent fixed counts from solvent "blanks". The standard deviation found for a single result increased from $\pm 0.06_{4}$ percent at $6.3 \times 10^{-3} \mathrm{M} \mathrm{Pu}$ to 1.23 percent at $1.9 \times 10^{-3} \mathrm{M}$ Pu. From the summary of these results in Table 4 it is clear that the error limiting the precision which can be attained by the method, under the conditions used, is that from the statistical fluctuations of counting. Note that the volumetric error of the procedure need not exceed a relative standard deviation of \pm 0.1 percent - negligible for these counting times even with no background. At the level of background obtained even the instrument error, which is characterized above, is a small effect. 
Table 3

RESULTS OF A CALIBRATION, COUNT RATE VS MOLARITY, FOR X-RAY SPECTROMETRIC DETERMINATION OF PLUTONIUM IN 1 M NITPIC ACTD SOLUTION. $54 \mathrm{KVP}, 43$ MA

\begin{tabular}{|c|c|c|c|c|c|c|c|c|c|}
\hline \multirow{2}{*}{$\begin{array}{l}\text { Pu } \\
\text { Molarity } \\
\times 10^{3}\end{array}$} & \multirow{2}{*}{$\begin{array}{l}\text { No. of } \\
\text { Determi- } \\
\text { nations }\end{array}$} & \multirow{2}{*}{$\begin{array}{c}\text { Time for } \\
128,000 \text { Counts } \\
(\mathrm{sec})\end{array}$} & \multirow{2}{*}{$\begin{array}{c}\text { Total } \\
\text { Count Rate } \\
(\text { cps })\end{array}$} & \multirow{2}{*}{$\begin{array}{c}\text { Net Count } \\
\text { Rate (total } \\
\text { minus } \\
149.4 \text { cps) } \\
\text { (cps) }\end{array}$} & \multirow{2}{*}{$\begin{array}{l}\text { Fraction } \\
\text { of Total } \\
\text { Counts } \\
\text { Due to } \\
\text { Pu }\end{array}$} & \multicolumn{2}{|c|}{$\begin{array}{l}\text { Per Cent } \\
\text { Deviation } \\
\text { Found }\end{array}$} & \multicolumn{2}{|c|}{$\begin{array}{c}\text { Per Cent } \\
\text { Deviation } \\
\text { Calculated from } \\
\text { Counting } \\
\text { Statistics }\end{array}$} \\
\hline & & & & & & $\begin{array}{c}\text { Av Dev } \\
\text { (d) }\end{array}$ & $\begin{array}{l}\text { Std Dev } \\
(\mathrm{d} x 1.25)\end{array}$ & $\begin{array}{c}\text { Av Dev } \\
(\sigma)\end{array}$ & $\begin{array}{c}\text { Std Dev } \\
(\sigma / 1.25)\end{array}$ \\
\hline 0 & 3 & $856.6 \pm 1.8$ & $149.4 \pm 0.3$ & & & & & & \\
\hline 1.94 & 3 & $613.3 \pm 1.8$ & $208.7 \pm 0.6$ & $59.3 \pm 0.7$ & $0.28 \mathrm{~A}$ & 1. $I_{5}$ & 1.4 & 1.3 & 1.0 \\
\hline 2.59 & 3 & $564.2 \pm 2.7$ & $226.9 \pm 1.1$ & $77.5 \pm 1.1$ & $0.34^{7}$ & $1.4^{\circ}$ & 1.8 & 1.05 & $0.8_{4}$ \\
\hline 3.24 & 3 & $518.4 \pm 1.1$ & $246.9 \pm 0.5$ & $97.5 \pm 0.6$ & $0.39_{4}$ & 0.6 & 0.8 & 0.9 & $0.7^{8}$ \\
\hline 3.89 & 3 & $481.3 \pm 1.0$ & $266.0 \pm 0.5_{5}$ & $116.6 \pm 0.6$ & $0.44^{4}$ & $0.5_{4}$ & 0.7 & 0.8 & $0.6_{4}$ \\
\hline 5.18 & 3 & $425.4 \pm 0.5$ & $300.9 \pm 0.3_{5}$ & $151.5 \pm 0.4$ & 0.49 & $0.3^{4}$ & 0.4 & 0.7 & $0.5_{4}^{4}$ \\
\hline 6.48 & 3 & $384.5+1.6$ & $332.9 \pm 1.4^{3}$ & $183.5 \pm 1.4^{6}$ & 0.55 & $0.7_{6}$ & 1.0 & 0.6 & $0.5^{4}$ \\
\hline
\end{tabular}

aThe \pm figure is the average deviation: $d=\frac{\sum(X-\bar{X})}{n}$

Table 4

RELIABILITY OF THE X-RAY SPECTROMETRIC DETERMINATION OF PLUTONIUY IN 1.00 MYDROCHLORIC ACID SOLUTION, $54 \mathrm{KVP}, 43$ MA

\begin{tabular}{|c|c|c|c|c|c|c|c|c|c|}
\hline \multirow{2}{*}{$\begin{array}{c}\text { Pu Molarity } \\
\text { x } 10^{3} \\
\text { (average) }\end{array}$} & \multirow{3}{*}{$\begin{array}{c}\begin{array}{c}\text { Mg of } \mathrm{Pu} \\
\text { in } 0.5 \mathrm{ml} \\
\text { Spectrometer } \\
\text { Cell }\end{array} \\
0.23\end{array}$} & \multirow{3}{*}{$\begin{array}{c}\begin{array}{c}\text { Number } \\
\text { of } \\
\text { Determi- } \\
\text { nations }\end{array} \\
9\end{array}$} & \multirow{3}{*}{$\begin{array}{c}\text { Per Cent } \\
\text { Standard } \\
\text { Deviation } \\
\text { of } \\
\begin{array}{c}\text { Molarity, } \\
\text { Found }\end{array} \\
0.10\end{array}$} & \multirow{2}{*}{$\begin{array}{c}\text { Time for } \\
128,000 \text { Counts } \\
\text { (average) } \\
\text { (sec) }\end{array}$} & \multirow{2}{*}{$\begin{array}{c}\text { Total } \\
\text { Count Rate } \\
\text { (average) } \\
\text { (cps) }\end{array}$} & \multirow{3}{*}{$\begin{array}{c}\begin{array}{c}\text { Net } \\
\text { Count } \\
\text { Rate } \\
\text { (average) } \\
\text { (cps) }\end{array} \\
46.5\end{array}$} & \multirow{3}{*}{$\begin{array}{l}\text { Fraction } \\
\text { of Total } \\
\text { Counts } \\
\text { Due to } \\
\text { Pu } \\
0.24\end{array}$} & \multicolumn{2}{|c|}{$\begin{array}{l}\text { Per Cent Standard } \\
\text { Deviation of Net } \\
\text { Count Rate }\end{array}$} \\
\hline & & & & & & & & Found $d^{b}$ & $\begin{array}{l}\text { Calculated from } \\
\text { Counting Statistics }\end{array}$ \\
\hline $1.899 \pm 0.001_{5}$ & & & & $660.0 \pm 2.1$ & $193.9 \pm 0.6$ & & & $1.2_{3}$ & 1.55 \\
\hline $2.525 \pm 0.004^{\prime \prime}$ & 0.3 & 2 & - & $614.7 \pm 4.1$ & $208.2 \pm 1.4$ & 61.4 & $0.29 \mathrm{~g}$ & - & 1.24 \\
\hline $3.80 \pm 0.002$ & 0.45 & 2 & - & $537.9 \pm 1.0$ & $238.0 \pm 0.5$ & 91.5 & $0.38^{\circ}$ & - & 0.92 \\
\hline $5.06 \pm 0.002$ & 0.6 & 2 & - & $484.6 \pm 1.9$ & $264.2 \pm 1.1$ & 116.7 & 0.44 & - & 0.79 \\
\hline $6.336 \pm 0.003$ & 0.76 & 9 & 0.06 & $439.2 \pm 1.4$ & $291.5 \pm 0.9$ & 144.4 & 0.496 & $0.6_{4}$ & 0.69 \\
\hline
\end{tabular}




\section{DISCUSSION}

The characteristics of secondary $\mathrm{X}$-ray emission and primary radiation scatter from a plutonium solution in dilute nitric acid under the conditions of this study are depicted by the linear rate-meter scan reproduced as Figure 2. It also illustrates features, such as the peak to background intensity ratio, which determine the choice of the characteristic line whose intensity is correlated with element concentration for the basis of the method. The relatively high background intensity from dilute aqueous solutions has been shown to be the feature which must be contended with in efforts to improve the method's precision and sensitivity. For these solutions the simple, albeit limited, expedient of counting for a longer time to accumulate more than 128,000 counts is denied by incipient bubble formation in the sample cell. The alternative of reducing the background has obvious advantages as well; it is being approached by the use of energy-selective detectors and other instrument modifications which offer the possibility of at least halving the present error. The accompanying increase in sensitivity for a given reliability is especially desired in analytical work with hazard bearers such as plutonium.

FIGURE 2

$X$-RAY SPECTROGRAM OF $6.5 \times 10^{-3} \mathrm{M}$ PLUTONIUM IN IM NITRIC ACID, $0.5 \mathrm{~m} \&$ CELL

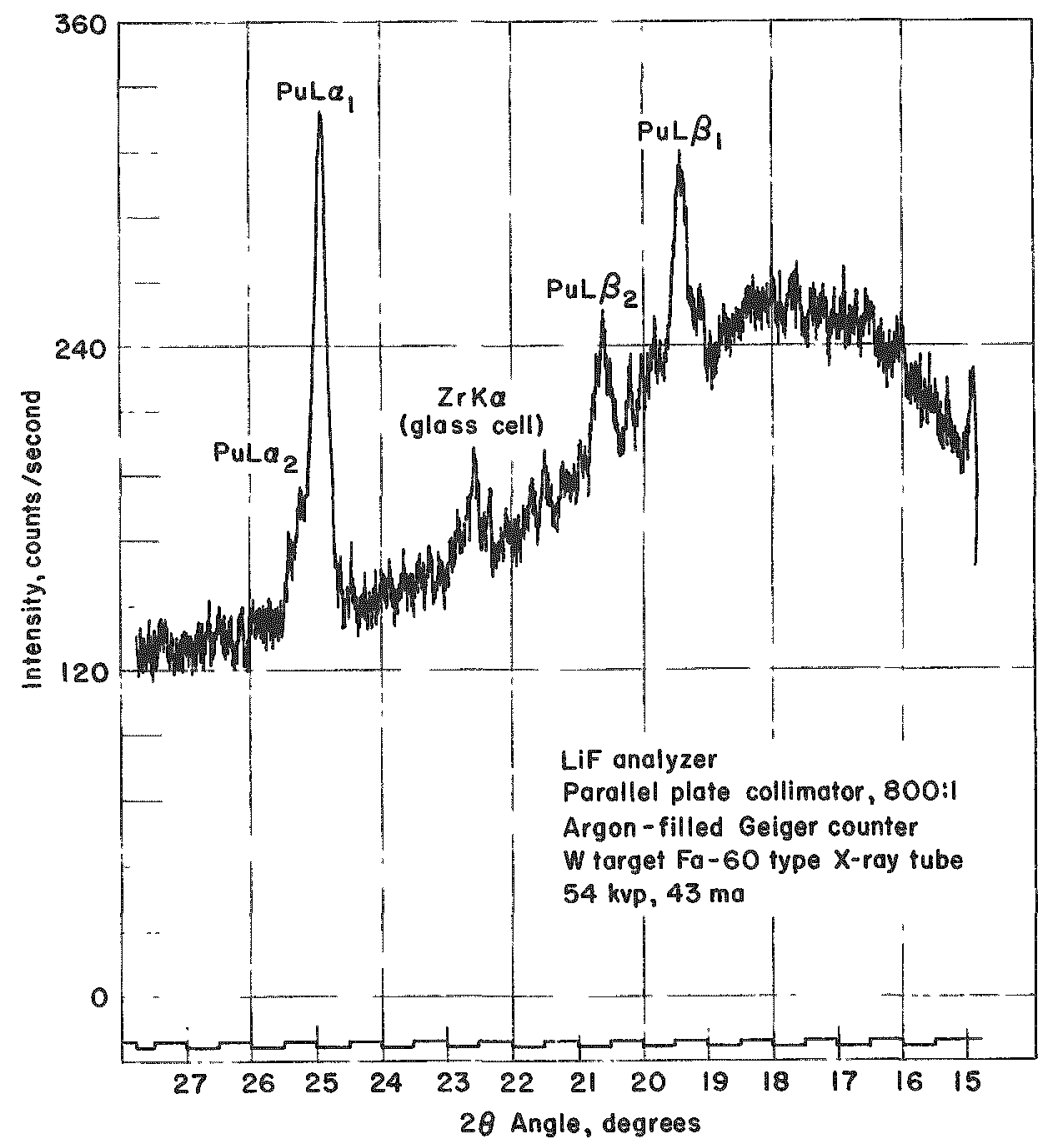


When a Geiger counter is used as the intensity-measuring device it is worthwhile to find a factor by which to correct the marked deviation from linearity in the calibration relation of count rate vs. concentration. Such a factor includes correction for loss of counts caused by coincidence in the counter and self-absorption in the solution. Once found it saves time in subsequent calibrations for a given analysis by lowering to two the number of concentration levels at which the relation must be established.

\section{ACKNOWLEDGEMENT}

The authors wish to recognize the careful, skillful work of M. Homa in this study. 